\title{
DETECTION OF WOLBACHIA IN LARVAE OF LOXOSTEGE STICTICALIS (PYRALOIDEA: CRAMBIDAE) IN EUROPEAN AND ASIAN PARTS OF RUSSIA
}

\author{
J.M. Malysh' ${ }^{1 *}$, S.M. Malysh ${ }^{1}$, D.S. Kireeva ${ }^{1}$, A.G. Kononchuk ${ }^{1}$, M.A. Demenkova ${ }^{2}$ \\ ${ }^{1}$ All-Russian Institute of Plant Protection, St. Petersburg, Russia \\ ${ }^{2}$ Institute of Cytology and Genetics SB RAS, Novosibirsk, Russia
}

*corresponding author,e-mail:malyshjm@mail.ru

\begin{abstract}
Beet webworm Loxostege sticticalis is a notorious pest widely distributed on the territory of Eurasia. Its outbreaks cause severe damage to crops in Russia and China. Here Wolbachia infection is reported for the first time in L. sticticalis. Larvae were sampled in Rostov, Saratov, Irkutsk Regions and Republic of Buryatia in 2005-2013. Primers targeting the wsp gene were used for the PCR screening of Wolbachia. Among 148 larvae, 35 were Wolbachia positive. Wolbachia prevalence rate ranged from 21 to $40 \%$ in the Asian and from 0 to $47 \%$ in the European part of Russia. The combined sample subsets were compared for European versus Asian part of Russia and 2005-2009 versus 2010-2013 timeframes. The prevalence rates of Wolbachia were not significantly different between two parts of Russia, but the endosymbiont presence (estimated for the total dataset) increased with time within the observation period.
\end{abstract}

Keywords: beet webworm, endosymbiont, prevalence rate, PCR

Received: 28.01 .2020

Accepted: 28.02 .2020

\section{Introduction}

Beet webworm Loxostege sticticalis L. is a notorious pest of numerous crops in European and Asian parts of Russia (Frolov et al., 2008), as well as in Northern China (Chen Xiao et al., 2008). Screening insect populations for naturally occurring parasites and pathogens is crucial for understanding the dynamics of pest populations. In particular, obligate intracellular parasites, such as Microsporidia, play an essential role in L. sticticalis density dynamics (Frolov et al., 2008). So far, other intracellular symbionts in populations of $L$. sticticalis have not been reported.

Bacteria of the Wolbachia genus are widespread endosymbionts of arthropods (Jeyprakash, Hoy, 2000). In certain species of Lepidoptera, Wolbachia may contribute to population biology of the hosts (Salunkhe et al., 2014), as it regulates reproductive processes (including sex determination) and influences host vitality and fertility in direct or indirect ways (Kageyama et al., 2002; Kageyama, Traut, 2004). The knowledge of Wolbachia distribution in insect populations is therefore of great interest, being important for a better understanding of the mechanisms underlying regulation of pest density dynamics (Sumi et al., 2017). Here, we report the first results of screening Wolbachia infection in L. sticticalis populations.

\section{Materials and Methods}

Beet webworm larvae were collected on crops and weeds in European and Asian parts of Russia (Fig. 1A). Insects were fixed with ethanol and stored at $-20^{\circ} \mathrm{C}$. Total DNA was extracted using a simplified protocol of Sambrook et al. (1989) without addition of phenol. For quality control of DNA samples, the primers LepF1/LepR1 (Hebert et al., 2004) specific for the barcoding region of mitochondrial cytochrome oxidase subunit I (COI) were used. DNA samples producing a specific signal with $C O I$-targeted primers were selected for further analysis. The Wolbachia infection was detected by amplification with primer set wsp81F/wsp691 (Zhou et al., 1998), specific to the locus of Wolbachia surface protein (wsp). We used DreamTaq Green PCR Master Mix (Thermo Fisher Scientific) with the following cycling conditions: initial denaturation at $95^{\circ} \mathrm{C}$ for $5 \mathrm{~min}, 35$ cycles of denaturation at $95^{\circ} \mathrm{C}$ for $1 \mathrm{~min}$, annealing at $54^{\circ} \mathrm{C}$ for $1 \mathrm{~min}$, elongation at $72^{\circ} \mathrm{C}$ for $1 \mathrm{~min}$, and final elongation step of $72^{\circ} \mathrm{C}$ for $5 \mathrm{~min}$. The amplicons were visualized using electrophoresis in $1 \%$ agarose gels with GeneRuler Ladder Mix molecular weight marker, 75-20000 bp (Thermo Fisher Scientific). The 95\% confidence intervals were estimated using the Clopper-Pearson method (Clopper, Pearson, 1934) which is routinely used when Wolbachia prevalence rates in small samples are examined (Yudina et al., 2016, Bykov et al., 2019). Estimates of the data reliability were obtained using the exact Fisher's test (Fisher, 1922), Pearson's chi-square criterion and chi-square criterion with Yates correction (Yates, 1934).

\section{Results and Discussion}

PCR with primers specific for $w s p$ gene fragment of Wolbachia has yielded amplicons with the expected size of $\sim 600$ bp (Fig. 1B) in 35 out of 148 analyzed samples. In a single sample set collected in 2005 from Rostov Region, Wolbachia infection has been detected in 2 out of 24 larvae, corresponding to the prevalence rate of $8.3 \%$. Thirty larvae collected in Saratov Region have been found as Wolbachia-free in 2006, but nearly half have been Wolbachia-positive in 2013.
In the Asian part of Russia, Wolbachia prevalence has ranged from 16.7 to $40 \%$ (Table 1). The quotes of infected insects have been significantly different in a pairwise comparison of populations in $50 \%$ of cases. In particular, population Salsk 2005 differs from Saratov 2013 and Irkutsk 2010, while Saratov 2006 differs from Saratov 2013, Irkutsk 2010 and Kabansk 2009 (Table 2). 


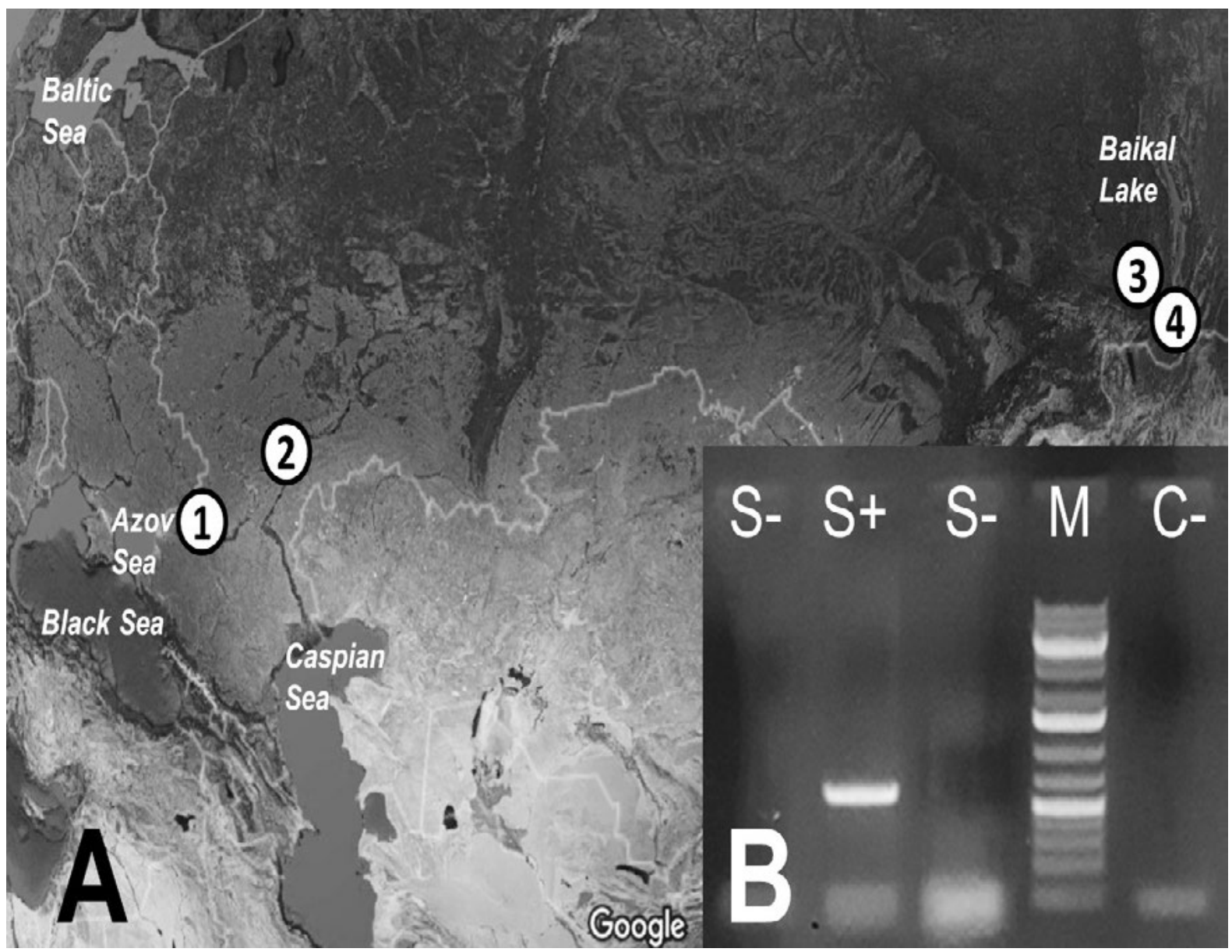

Figure 1. Detection of Wolbachia in Loxostege sticticalis. A: Sampling sites of L. sticticalis larvae in Salsk, Rostov region (1), Saratov, Saratov Region (2), Irkutsk, Irkutsk Region (3) and Kabansk, Buryatia (4). B: Electrophoretic profile of PCR samples negative (S-) and positive (S+) for Wolbachia, GeneRuler Ladder Mix molecular weight marker, 75-20000 bp (M) and negative control (C-)

Table 1. Prevalence rates of Wolbachia in Loxostege sticticalis larvae sampled across Russia

\begin{tabular}{|c|c|c|c|c|c|c|}
\hline \multirow[b]{2}{*}{ \# } & \multirow[b]{2}{*}{ Sampling site, year, collector } & \multirow[b]{2}{*}{ Coordinates } & \multirow{2}{*}{$\begin{array}{c}\text { Number } \\
\text { of analyzed } \\
\text { samples (N) }\end{array}$} & \multicolumn{3}{|c|}{ Wolbachia prevalence rates } \\
\hline & & & & $\begin{array}{l}\text { Number of posi- } \\
\text { tive samples, } n\end{array}$ & $\begin{array}{c}\text { Prevalence, } \% \\
(\mathrm{n} / \mathrm{N})\end{array}$ & $\begin{array}{c}95 \% \text { confidence } \\
\text { interval, } \%\end{array}$ \\
\hline 1 & Salsk, Rostov region, 2005, Malysh J.M., Tokarev Y.S. & $\begin{array}{l}46^{\circ} 30^{\prime} \mathrm{N} \\
41^{\circ} 19^{\prime} \mathrm{E}\end{array}$ & 24 & 2 & 8.3 & $1.0-27.0$ \\
\hline 2 & Saratov, Saratov Region, 2006, Silaev A.I. & $\begin{array}{l}51^{\circ} 27^{\prime} \mathrm{N} \\
46^{\circ} 12^{\prime} \mathrm{E}\end{array}$ & 30 & 0 & 0.0 & $0.0-11.6$ \\
\hline 3 & Saratov, Saratov Region, 2013, Silaev A.I. & $\begin{array}{l}51^{\circ} 27^{\prime} \mathrm{N} \\
46^{\circ} 12^{\prime} \mathrm{E}\end{array}$ & 30 & 14 & 46.7 & $28.3-65.7$ \\
\hline 4 & Irkutsk, Irkutsk Region, 2010, Belyakova N.A. & $\begin{array}{l}52^{\circ} 16^{\prime} \mathrm{N} \\
104^{\circ} 19^{\prime} \mathrm{E}\end{array}$ & 30 & 12 & 40.0 & $22.7-59.4$ \\
\hline 5 & Kabansk, Buryatia, 2009, Akhanaev Y.B. & $\begin{array}{l}52^{\circ} 09^{\prime} \mathrm{N} \\
106^{\circ} 36^{\prime} \mathrm{E}\end{array}$ & 34 & 7 & 20.6 & $8.7-37.9$ \\
\hline \multicolumn{2}{|c|}{ Total } & & 148 & 35 & 23.6 & - \\
\hline
\end{tabular}

Table 2. Statistical significance of differences of Wolbachia prevalence between Loxostege sticticalis larval populations according to exact Fisher's test

\begin{tabular}{l|c|c|c|c|c}
\hline \hline \multicolumn{1}{c}{$\begin{array}{c}\text { Local population } \\
\text { (place and year) }\end{array}$} & Salsk 2005 & Saratov 2006 & Saratov 2013 & Irkutsk 2010 & Kabansk 2009 \\
\hline Salsk 2005 & $=$ & 0.1929 & $\mathbf{0 . 0 1 3 6}$ & $\mathbf{0 . 0 0 7 4}$ & 0.1394 \\
Saratov 2006 & & $=$ & $\mathbf{0 . 0 0 0 2}$ & $\mathbf{0 . 0 0 0 1}$ & $\mathbf{0 . 0 0 8 7}$ \\
Saratov 2013 & & & $=$ & 0.2020 & 0.0816 \\
Irkutsk 2010 & & & & $=$ & 0.0533 \\
Kabansk 2009 & & & & & $=$ \\
\hline \hline
\end{tabular}


To further test possible differences in Wolbachia prevalence rates over time and place, we have compared the combined sample subsets of European versus Asian part of Russia and 2005-2009 versus 2010-2013 timeframes. In European part of Russia (Salsk + Saratov), the average Wolbachia prevalence rate have been $19.0 \%(\mathrm{~N}=84)$, while in Asian part (Irkutsk + Kabansk) this index has reached $29.7 \%(\mathrm{~N}=64)$. According to Pearson's chi-square criterion $\left(\chi^{2}=2.271\right)$, the prevalence rates of Wolbachia does not depend on the geographical origin of the sampled populations, which indirectly confirms the conclusion that the beet webworm populations belong to a single metapopulation (Jiang et at., 2010). Meanwhile, in 2005-2009 (number of positive samples per 30 samples $<10$ ) and 2010-2013 (number of positive samples per 30 samples $>10)$, the average Wolbachia prevalence rates were $10.7 \%(\mathrm{~N}=88)$ and $43.3 \%(\mathrm{~N}=60)$, respectively. According to chi-square criterion with Yates correction for continuity $\left(\chi^{2}=19.819\right)$, the Wolbachia prevalence rate does not depend on the sampling timeframe $(\mathrm{p}=0.01)$. Similar trend have been observed when the timeframe of 2005-2006 (3.7\%) have been tested against 2009-2013 (35.1\%). These findings clearly indicate that the endosymbiont prevalence rate have increased with time within the observation period.

Prevalence rates of Wolbachia in insect hosts may significantly vary over time and space. For example, in pyraloid moths of the genus Ostrinia, Wolbachia has been found in all examined populations in European part of Russia, and the prevalence rates have depended on the species and the forage plant (Tokarev et al., 2018). Long-distance migrations are likely to provide symbiont exchange between local populations of the beet webworm, but various factors may affect the temporal dynamics of Wolbachia infection, revealed in the present study.

According to the Russian Agricultural Center (https:// rosselhoscenter.com/), low density of beet webworm was reported in the Russian Federation in 2005 and 2006. From 2008 to 2014 , the period of relatively high density was observed in Russia, with maximum in 2009, when the pest outbreaks occurred throughout the entire pest area from the Southern and Central Federal Districts to the Far Eastern Federal District. We have noticed a trend that during the period of low pest abundance, infection rate of Wolbachia was at its minimum, while during the period of high abundance, it was increasing over time. A long depression period of the pest, observed from 2015 to 2018, has been followed by an increase in the number of the beet webworm in Siberia. In the coming years, we expect to collect more data and to verify the relationship between the pest number and the frequency of Wolbachia infection.

The Wolbachia infection has been found for the first time in populations of L. sticticalis in the present study. Although the sampling sites are not numerous, it is obvious that the bacterium is present in the majority of local samplings. The beet webworm tends to form a single metapopulation on the territory of Eurasia due to its high migratory activity. In a given locality, the endosymbiotic bacterium may change its state over time from absence (presence at undetectable levels) to presence in a half of the insect population, as shown for the samplings from Saratov. The examined dataset does not allow to determine whether the fluctuations of Wolbachia prevalence rates is adaptive or stochastic. Further studies are necessary to elucidate the genetic diversity of Wolbachia and its biological role in populations of the beet webworm.

\section{Acknowledgements}

The research is supported by Federal Contract for All-Russian Institute of Plant Protection (project \# A16-116080510094-3) and Russian Foundation for Basic Research (grant \# 18-316-00099). The authors are thankful to Ilinsky Y.Y. (Institute of Cytology and Genetics of SB RAS) for the consultation, Silaev A.I. (All-Russian Institute of Plant Protection), Belyakova N.A. (AllRussian Institute of Plant Protection), Akhanaev Y.B. (Institute of Systematics and Ecology of Animals of SB RAS) for insect sampling and Tokarev Y.S. (All-Russian Institute of Plant Protection) for the help with insect sampling and English translation.

\section{References}

Bykov RA, Yudina MA, Gruntenko NE, Zakharov IK et al (2019) Prevalence and genetic diversity of Wolbachia endosymbiont and mtDNA in Palearctic populations of Drosophila melanogaster. BMC Evol Biol 19(Suppl 1):48. https://doi.org/10.1186/s12862-019-1372-9

Chen X, Zhai B, Gong R, Yin M et al (2008) Source area of spring population of meadow moth, Loxostege sticticalis L. (Lepidoptera: Pyralidae), in Northeast China. Acta Ecol Sin 28(4):1521-1535. http://doi.org/10.1016/ S1872-2032(08)60054-2

Clopper CJ, Pearson ES (1934) The use of confidence or fiducial limits illustrated in the case of the binomial. Biometrika 26(4):404-413. https://doi.org/10.1093/biomet/26.4.404

Fisher RA (1922) On the interpretation of $\chi 2$ from contingency tables, and the calculation of P. J. Royal Stat. Soc. 85 (1):8794. https://doi.org/10.2307/2340521

Frolov AN, Malysh YuM, Tokarev YuS (2008) Biological features and population density forecasts of the beet webworm Pyrausta sticticalis L. (Lepidoptera, Pyraustidae) in the period of low population density of the pest in
Krasnodar Territory. Entomol Rev 88(6):666-675. http://doi. org/10.1134/S0013873808060055

Hebert PDN, Penton EH, Burns JM, Janzen DH, Hallwachs $\mathrm{W}$ (2004) Ten species in one: DNA barcoding reveals cryptic species in the neotropical skipper butterfly Astraptes fulgerator. Proc Natl Acad Sci USA 101:14812-14817. http://doi.org/10.1073/pnas.0406166101

Jeyaprakash A, Hoy MA(2000) Long PCR improves Wolbachia DNA amplification: wsp sequences found in $76 \%$ of sixtythree arthropod species. Insect Mol Biol 9(4):393-405

Jiang XF, Cao WJ, Zhang L, Luo LZ (2010) Beet webworm (Lepidoptera: Pyralidae) migration in China: evidence from genetic markers. Environ Entomol 39(1):232-242. http:// doi.org/10.1603/EN08315

Kageyama D, Nishimura G, Hoshizaki S, Ishikawa Y (2002) Feminizing Wolbachia in an insect, Ostrinia furnacalis (Lepidoptera: Crambidae). Heredity 88(6):444-449. http:// doi.org/10.1038/sj.hdy.6800077

Kageyama D, Traut W (2004) Opposite sex-specific effects of Wolbachia and interference with the sex determination of its 
host Ostrinia scapulalis. Proc Biol Sci 271(1536):251-258. http://doi.org/10.1098/rspb.2003.2604

Russian Agricultural Center. Reviews and predictions. URL: https://rosselhoscenter.com/index.php?option=com_conte nt\&view $=$ category\&layout $=$ blog $\& \mathrm{id}=849 \&$ Itemid $=1621$ (01.02.2020)

Salunkhe RC, Narkhede KP, Shouche YS (2014) Distribution and evolutionary impact of Wolbachia on butterfly hosts. Indian J Microbiol 54(3):249-254. http://doi.org/10.1007/ s12088-014-0448-x

Sambrook J, Fritsch E, Maniatis T (1989) Molecularcloning: alaboratory manual. Cold spring harbor laboratory. Cold Spring Harbor, New York

Sumi T, Miura K, Miyatake T (2017) Wolbachia density changes seasonally amongst populations of the pale grass blue butterfly, Zizeeria maha (Lepidoptera: Lycaenidae). PLoS One 12(4):e0175373. http://doi.org/10.1371/journal. pone. 0175373

Вестник защиты растений, 2020, 103(1), с. 49-52

OECD+WoS: 1.06+IY (Entomology)
Tokarev YS, Yudina MA, Malysh JM, Bykov RA et al (2018) Prevalence Rates of the Endosymbiotic Bacterium of the Wolbachia Genus in Natural Populations of Ostrinia nubilalis and Ostrinia scapulalis (Lepidoptera: Pyraloidea: Crambidae) in Southwestern Russia. Russian Journal of Genetics: Applied Research 8(2):172-177. https://doi. org/10.1134/S2079059718020119

Yates F (1934) Contingency table involving small numbers and the $\chi^{2}$ test. Suppl J Royal Stat Soc 1(2):217-235.

Yudina MA, Dubatolov VV, Bykov RA, Ilinsky YuYu (2016) Wolbachia infection in populations of the coniferous forest pest Dendrolimus superans sibiricus Tschetverikov, 1908 (Lepidoptera: Lasiocampidae). Russian Journal of Genetics: Applied Research 20(6):899-903. https://doi.org/10.18699/ VJ16.208 (In Russian)

Zhou W, Rousset F, O’Neil S (1998) Phylogeny and PCRbased classification of Wolbachia strains using wsp gene sequences. Proc Biol Sci 265(1395):509-515

http://doi.org/10.31993/2308-6459-2020-103-1-49-52

\title{
ОБНАРУЖЕНИЕ WOLBACHIA В ГУСЕНИЦАХ LOXOSTEGE STICTICALIS \\ Краткое сообщение (PYRALOIDEA: CRAMBIDAE) В ЕВРОПЕЙСКОЙ И АЗИАТСКОЙ ЧАСТЯХ РОССИИ
}

\author{
Ю.М. Малыш ${ }^{1 *}$, С.М. Малыш ${ }^{1}$, Д.С. Киреева ${ }^{1}$, А.Г. Конончук ${ }^{1}$, М.А. Деменкова ${ }^{2}$ \\ ${ }^{1}$ Всероссийский научно-исследовательский институт защиты растений, Санкт-Петербург \\ ${ }^{2}$ Институт циитологии и генетики СО РАН, Новосибирск \\ *ответственный за переписку, e-mail: malyshjm@mail.ru
}

Луговой мотылёк Loxostege sticticalis - общеизвестный вредитель, широко распространённый на территории Евразии. Его вспышки вызывают серьёзные повреждения сельскохозяйственных культур в России и Китае. Здесь мы впервые сообщаем о заражённости L. sticticalis вольбахией. Гусеницы были собраны в Ростовской, Саратовской, Иркутской областях и Республике Бурятия в 2005-2013. Для скрининга использовали ПЦР со специфичными праймерами, нацеленными на ген вольбахии wsp. Среди 148 гусениц было обнаружено 35 особей, давших положительный сигнал на Wolbachia. Показатель распространённости вольбахии варьировал от 21 до $40 \%$ в азиатской и от 0 до $47 \%$ в европейской частях России. Объединённые выборки сравнивались по месту сбора насекомых (европейская и азиатская части России) и по годам сборов (2005-2009 и 2010-2013). Показатели распространённости Wolbachia достоверно не различались между двумя частями России, при этом присутствие эндосимбионта (в отношении общей выборки) увеличивалось со временем в течение периода наблюдения.

Ключевые слова: луговой мотылёк, эндосимбионт, уровень распространённости, ПЦР 